\title{
Urgensi Peran Orang Tua dalam Penanaman Nilai Persatuan pada Anak di Daerah Transmigran
}

\author{
Yasir Marzuqi ${ }^{1 凶}{ }^{\bowtie a r z u k i}{ }^{1}$ \\ Pendidikan Pancasila dan Kewarganegaraan, Universitas Negeri Yogyakarta, Indonesia(1) \\ DOI: $\underline{10.31004 / o b s e s i . v 6 i 4.2268}$
}

\begin{abstract}
Abstrak
Nilai persatuan merupakan salah satu nilai penting yang harus diterapkan oleh seluruh masyarakat agar terciptanya kemakmuran bangsa dan negara Indonesia. Oleh sebab itu, orang tua memiliki peran penting dalam menanamkan nilai persatuan pada anak sejak dini, agar implementasi nilai persatuan dapat diwujudkan dengan minimnya konflik antar kelompok masyarakat. Tujuan penelitian ini untuk mendeskripsikan bagaimana peran orang tua dalam menanamkan nilai persatuan pada anak usia dini di daerah transmigran, Dsn. Sri Mulyo, Ds. Pematang Kolim, Kec. Pelawan, Kab. Sarolangun, Jambi. Menggunakan jenis penelitian kualitatif dengan pendekatan deskriptif. Selanjutnya teknik pengumpulan data yang digunakan diantaranya observasi, wawancara dengan orang tua, anak, dan tokoh masyarakat yang ada, serta dokumentasi. Teknik analisis data yang digunakan yaitu triangulasi teknik dan triangulasi sumber. Hasil penelitian menunjukkan, masih kurang sesuainya peran orang tua dalam menanamkan nilai persatuan pada anak terutama di daerah transmigran, seperti halnya peran sebagai pendidik, pengasuh, motivator, dan model bagi anak.
\end{abstract}

Kata Kunci: peran; orang tua; persatuan.

\begin{abstract}
The value of unity is one of the important values that must be applied by all people in order to create the prosperity of the Indonesian nation and state. Therefore, parents have an important role in instilling the value of unity in children from an early age, so that the implementation of the value of unity can be realized with minimal conflict between community groups. The purpose of this study is to describe how the role of parents in instilling the value of unity in early childhood in transmigrant areas, Dsn. Sri Mulyo, Ds. Pematang Kolim, Kec. Pelawan, Kab. Sarolangun, Jambi. Using this type of qualitative research with a descriptive approach. Furthermore, the data collection techniques used include observation, in-depth interviews, and documentation. The data analysis technique used are technique triangulation and source triangulation. The results of the study indicate that the role of parents in instilling the value of unity in children, especially in transmigrant areas, are still not appropriate, as well as the role of educators, caregivers, motivators, and models for children.
\end{abstract}

Keywords: role; parent; unity.

Copyright (c) 2021 Yasir Marzuqi, Marzuki.

$\triangle$ Corresponding author :

Email Address : yasirmarzuqi.2020@student.uny.ac.id (Depok, Sleman, Yogyakarta, Indonesia)

Received 10 November 2021, Accepted 30 January 2022, Published 12 February 2022 


\section{PENDAHULUAN}

Pemerintah Indonesia telah menerapkan teori klasik imigrasi sejak 63 tahun yang lalu, merelokasi pendatang dari Jawa dan Madura ke tempat-tempat di luar Jawa, seperti Sumatera, Sulawesi, Kalimantan dan Papua, hingga dari beberapa anggota pertahanan militer. Hal tersebut dikarenakan Indonesia dianggap strategis dan ada ketakutan akan resistensi dari penduduk setempat (Dirjen PKPPT, 2015). Tujuan utama transmigrasi bukanlah pemerataan penduduk, melainkan perbaikan kondisi ekonomi yang kurang menguntungkan (Maulana et al., 2019). Namun karena perbedaan latar belakang budaya dan akses sumber daya antar kelompok sosial, program migrasi berpotensi menimbulkan konflik di daerah tujuan (Maulana et al., 2019). Salah satu fakta yang berkontribusi pada masalah konflik jangka panjang adalah perkembangan transmigrasi, yang seringkali bias imigran. Segala jenis bantuan diberikan kepada masyarakat hanya di Unit Permukiman Transmigrasi (UPT), sementara penduduk sekitar yang sama miskinnya kurang mendapat perhatian (Sarmita, 2014). Ketidakseimbangan ini tentu akan menimbulkan prasangka buruk di antara kelompok masyarakat, yang berdampak pada konflik jangka panjang antara masyarakat lokal dan pendatang.

Upaya mencapai sasaran program transmigrasi tidaklah mudah. Hal tersebut dikarenakan transmigrasi bersifat majemuk, baik dari segi etnik, ras, budaya, adat istiadat, maupun agama, sehingga memungkinkan lahirnya benturan atau konflik antar etnik di wilayah baru (Punia \& Budi Nugroho, 2020). Terdapat beberapa factor penyebab munculnya konflik diantaranya, adanya ketimpangan yang kuat dalam penguasaan kekayaan yang dianggap salah oleh masyarakat, tidak ada jaminan fisik, ketidaksetaraan status, bersifat personal dan kedudukan yang kuat, ketidakberdayaan kesatuan keluarga sebagai tempat untuk mengembangkan diri (Maulana et al., 2019). Salah satu konflik yang masih sering terjadi hingga saat ini adalah ketimpangan hak milik tanah antara masyarakat lokal dan transmigran. Konflik tersebut hampir terjadi di beberapa wilayah transmigrasi, salah satunya Bali yang lebih tepatnya adalah Bali diaspora di Bolaang Mongondow yang terjadi pada tahun 1997. Etnik setempat menuntut ganti rugi kepada pemerintah atau mengembalikan kepada yang berhak atas tanah yang dahulu diberikan kepada transmigran. Tuntutan tersebut didasarkan alasan bahwa tanah-tanah tersebut merupakan tanah adat yang diwariskan oleh leluhur mereka (Sumolang Steven dan Peggy Janeke, 2018).

Multikulturalisme merupakan realitas yang tidak dapat dipisahkan di Indonesia, dapat menjadi aset bagi bangsa dan negara Indonesia, bahkan dapat memicu perpecahan diantara kelompok masyarakat Indonesia. Masyarakat multikultural merupakan masyarakat dengan potensi konflik yang sangat besar, sehingga perlu disadari sejak dini bagaimana setiap kelompok masyarakat harus bekerjasama untuk mencegahnya. Konflik dalam masyarakat multikultural dapat muncul karena masyarakat memiliki berbagai kepentingan dalam institusi, organisasi, bahkan kelas sosial yang selalu berbeda dengan kelompok masyarakat lainnya (Suharno, 2015). Konflik dalam kehidupan sosial merupakan suatu hal yang tidak dapat dipisahkan. Sehingga, perlu banyak upaya yang harus dilakukan untuk meminimalisir hal tersebut salah satunya adalah dengan menanamkan nilai persatuan sejak dini pada anak, dimulai dari lingkungan keluarga. Penanaman nilai persatuan sejak dini menjadi aset bagi integrasi bangsa dan negara Indonesia di masa yang akan datang.

Integrasi merupakan suatu kondisi dimana kelompok-kelompok etnis untuk beradaptasi dan menjadi konformitas terhadap kebudayaan mayoritas, namun tetap mempertahankan buadaya merek sendiri. Integrasi memiliki dua rasa, dimana ketika control atas konflik dan penyimpangan sosial dalam suatu sistem sosial tertentu dan menciptakan keselarasan, serta menyatukan unsur-unsur tertentu (Miyanti et al., 2017). Untuk meningkatkan integrasi antar masyarakat lokal dan masyarakat transmigran maka pada diri 
masing-masing harus mengendalikan perbedaan atau konflik yang ada pada suatu kekuatan bangsa bukan sebaliknya. Selain hal tersebut, setiap warga masyarakat merasa asing dapat mengisi kebutuhan antara satu dengan yang lainnya. Hal ini yang tentu saja diharapkan dapat terlaksana pada masyarakat transmigrasi, dengan adanya transmigrasi masyarakat yang multikultural maka akan tercipta integrasi (Miyanti et al., 2017). Selain itu, nilai persatuan itu sendiri jika ditinjau dari sudut pandang dinamikanya, menjelaskan tentang suatu proses yang dinamis berdirinya bangsa dan negara Indonesia, yaitu merupakan suatu proses persatuan untuk wilayah, bangsa dan negara Indonesia (Suryawan \& Danial, 2016). Nilai persatuan, menjadi sebuah landasan bagi seluruh masyarakat Indonesia untuk mencapai kerukunan di tengah perbedaan yang ada. Melihat permasalahan tersebut, upaya kesadaran bagi masyarakat Indonesia untuk mengimplementasikan nilai persatuan dalam kehidupannya sehari-hari dirasa sangat penting. Akan tetapi persoalan integrasi bangsa dan negara Indonesia di tengah multikulturalisme yang ada bukanlah hal yang mudah. Kesadaran masyarakat yang masih rendah masih terbukti dengan adanya konfik antar kelompok masyarakat yang masih terus ada hingga saat ini.

Peristiwa konflik antar kelompok masyarakat di Indonesia merupakan permasalahan yang sangat menyayat hati dimana, keberanekaragaman yang ada seharusnya menjadi satu kesatuan yang perlu dijaga bersama justru menjadi salah satu pemantik konflik antar masyarakat yang ada terutama di daerah transmigrasi. Konflik yang melibatkan antara masyarakat transmigran dan masyarakat lokal pernah terjadi di salah satu daerah di Indonesia dan menjadi pembelajaran untuk seluruh masyarakat Indonesia adalah konflik yang terjadi di Sampit Kotim Kalimantan Tengah, dengan melibatkan warga etnis Madura dan etnis Dayak. Konflik ini menimbulkan ratusan bahkan ribuan korban jiwa yang didominasi oleh warga Madura. Konflik tersebut mengakibatkan arus pengungsian kurang lebih 55.323 jiwa yang pada akhirnya terjadi penelantaran. Terdapat 357 pengungsi yang meninggal dunia, munculnya berbagai macam penyakit karena kualitas hidup yang tidak sesuai. Hal tersebut tentu berdampak pada rasa trauma masyarakat yang diharapkan tidak terjadi lagi dalam kehidupan dan peradaban manusia (Suharno, 2015). Memahami hal tersebut tentu permasalahan perbedaan latar belakang baik budaya, adat istiadat dan lain sebagainya terutama di wilayah sasaran transmigrasi perlu dilakukan pendewasaan sejak dini baik dari segi memahami pentingnya persatuan agar kondisi tersebut dapat diminimalisir dengan baik.

Selain itu, terdapat salah satu penelitian yang menjelaskan tentang bagaimana rentannya konflik antra kelompok masyarakat transmigran dan masyarakat lokal. Salah satu temuan penelitian menunjukkan adanya kesenjangan sosial di Kecamatan Tiworo Tengah, dimana kesenjangan tersebut dilahirkan segregasi antara penduduk lokal dengan komunitas pendatang dalam dua matra kehidupan sosial tersebut. Kesenjangan sosial ekonomi di Kecamatan Tiworo Tengah dapat diidentifikasi melalui kepemilikan kekayaan masyarakat. Sedangkan tingkat ekonomi diatas kategori cukup didominasi oleh masyarakat pendatang yang berasal dari suku Bali, Jawa, dan Bugis (Monstasir et al., 2017). Hal tersebut selaras dengan apa yang terjadi didaerah transmigrasi di beberapa wilayah Jambi salah satunya di Dusun Sri Mulyo, Desa Pematang Kolim, Kecamatan Pelawan, Kabupaten Sarolangun, yang mana para transmigrant dibekali oleh pemerintah dengan penjatahan lahan rata-rata 2 (dua) Ha untuk masing-masing transmigran per-kepala keluarga. Terdapat dua jenis lahan yang diterima, dengan jumlah anggota keluarga rata-rata 3-4 orang. Lahan pertama terletak disekeliling rumah yang telah disediakan (pekarangan) lahan tersebut dapat ditanami tanaman berumur pendek seperti jagung, ubi, kacang tanah, dan kedelai. Untuk lahan kedua ditanami tanaman keras yang berumur panjang. Lahan-lahan tersebut dimanfaatkan transmigrant tidak hanya untuk pertanian, melainkan untuk perkebunan seperti karet dan kelapa sawit. Di kawasan transmigran terutama di wilayah Jambi tanaman karet merupakan salah satu komoditi yang paling banyak ditanam oleh para transmigran dan juga masyarakat lokal karena cepat mendapatkan keuntungan (Yulmardi, 2019). 
Kondisi tersebut tidak jarang menjadi akar permasalahan konflik antar masyarakat transmigran dan masyarakat lokal. Konflik pernah dan bahkan masih terjadi di beberapa daerah di Jambi, seperti di Kecamatan Lembah Masurai, Kabupaten Sarolangun, Jambi, konflik terjadi antara masyarakat transmigrant yang berasal dari Lampung, Sumatera Selatan, dan Bengkulu yang telah membuka kebun didaerah tersebut sejak tahun 1990-an. Konflik tersebut hampir merata terjadi diberbagai daerah di Jambi, mulai dari Kabupaten Sarolangun, Kabupaten Merangin, Kabupaten Tebo dan beberapa kabupaten lainnya (Lindayanti \& Zaiyardam, 2016). Permasalahan konflik antar kelompok masyarakat transmigran dan masyarakat lokal tidak jarang merambat hingga perpecahan antar kelompok anak-anak hingga remaja yang berada dilokasi tersebut. Masih banyak ditemukan para remaja yang sering bergesekan karena perbedaan yang ada. Hasil penelitian awal yang dilakukan oleh peneliti di salah satu desa transmigran di Desa Pematang Kolim, Kecamatan Pelawan, Kabupatan Sarolangun, Jambi menunjukkan bahwa, masih sering terjadi perkelahian antara anak-anak bahkan hingga golongan remaja dikarenakan latar belakang pertemanan yang berbeda sehingga timbul sinisme antar kelompok remaja yang ada. Salah satu kasus yang pernah terjadi adalah perkelahian antara remaja yang berasal dari suku Jawa dengan masyarakat lokal (J. Piyan, 22 Februari 2019).

Selaras dengan apa yang disampaikan oleh Alimuddin. Hos \& M. (2019) konflik budaya terutama masyarakat transmigran dan masyarakat lokal yang tidak dapat berbaur dapat menyebabkan permasalahan salah satunya timbulnya kenakalan remaja karena perbedaan prinsip yang tidak jarang melibatkan orang tua. Nilai persatuan menjadi nilai penting untuk meningkatkan persatuan antara masyarakat transmigran dan masyarakat lokal. Upaya penanaman nilai persatuan sejak dini menjadi langkah dini untuk memajukan masa depan bangsa dengan lebih baik. Kemajemukan daerah transmigrant justru menjadi peluang untuk kemajuan wilayah tersebut. Pola pengembangan masyarakat dapat dilakukan antara masyarakat transmigrant dan masyarakat lokal untuk memajukan daerah bersama (Achmad et al., 2019). Orang tua memiliki peran penting untuk mulai menanamkan diri kepada anak tentang pentingnya makna persatuan bagi keutuhan bangsa dan negara. Sehingga, pembiasaan implementasi nilai persatuan yang dilakukan sejak dini bertujuan untuk meningkatkan kemakmuran di masa yang akan datang.

Konflik yang terjadi antara masyarakat transmigran dan masyarakat lokal sangat berpengaruh terhadap perkembangan anak. Sejarah konflik yang pernah terjadi dapat menjadi pengalaman buruk bagi pola pikir anak dalam menyikapi sesuatu. Hubungan antara peran orang tua dalam mengasuh anak sangat berpengaruh terhadap bagaimana perkembangan anak dalam menyikapi permasalahan yang ada. Dari hasil penelitian yang dilakukan oleh Utami (2021) menjelaskan bahwa hubungan pola asuh orang tua di rumah dengan perilaku anak, terutama pada kenakalan dan pengendalian diri pada remaja karena remaja merupakan masa peralihan dari anak-anak menuju dewasa dan sering terjadi konsep atau pemahaman yang salah tentang peran orang tua dan pola asuh orang tua terhadap remaja (Nur Utami \& Raharjo, 2019). Kualitas hubungan antara orang tua dan anak yang kurang baik dapat berdampak pada mental anak, hal yang biasa terjadi adalah depresi pada anak serta kecemasan, yang bahkan hal tersebut jarang dilihat oleh orang tua yang nantinya berdampak pada kehidupan sosial anak di masa yang akan datang (Tolliver-Lynn et al., 2021). Sehingga dengan adanya permasalahan yang terjadi antara masyarakat lokal dan masyarakat transmigrant pada dasarnya perlu upaya orang tua untuk memberikan pemahaman kepada anak, terutama untuk meningkatkan persatuan di masa yang akan datang. Sehingga terjadi hubungan sosial yang sesuai dengan apa yang diharapkan.

Sebagai generasi penerus tentu kondisi tersebut bukanlah kondisi yang diharapkan. Tentu perubahan menuju hal yang lebih baik perlu untuk diterapkan salah satunya implementasi nilai yang baik di masa yang akan datang. Sehingga perlu diketahui bagaimana peran orang tua dalam menanamkan nilai persatuan pada anak, hal tersebut dianggap urgen karena orang tua memiliki peran penting dalam pembentukan karakter anak terutama 
implementasi nilai persatuan. Sehingga keberanekaragaman yang ada dapat dibalut dengan indah dalam persatuan Indonesia. Berdasarkan permasalahan tersebut peneliti, melakukan penelitian mengenai peran orang tua dalam menanamkan nilai persatuan pada anak usia dini di Desa Pematang Kolim, Kecamatan Pelawan, Kabupaten Sarolangun, Provinsi Jambi. Penelitian ini bertujuan untuk mendeskripsikan bagaimana peran orang tua dalam menanamkan nilai persatuan pada anak di daerah transmigran, Desa Pematang Kolim. Penelitian ini diharapkan dapat bermanfaat sebagai pemberi informasi mengenai peran orang tua dalam menanamkan nilai persatuan pada anak di Daerah Transmigrasi.

\section{METODOLOGI}

Jenis penelitian yang digunakan dalam penelitian ini adalah kualitatif dengan pendekatan deskriptif. Peneliti bertujuan untuk mendeskripsikan secara jelas mengenai peran orang tua dalam menanamkan nilai persatuan pada anak daerah transmigran di Desa Pematang Kolim, Kecamatan Pelawan, Kabupaten Sarolangun, Jambi. Menurut (Kusumastuti \& Ahmad Mustamil Khoiron, 2019) berpendapat bahwa penelitian kualitatif pada dasarnya digunakan untuk memahami bagaiman fenomena-fenomena yang dialami oleh subjek penelitian yang ditentukan oleh peneliti berdasarkan objek permasalahan yang dikaji. Subjek dalam penelitian berjumlah 33 orang dengan rincian sebagai berikut: orang tua yang merupakan orang tua sah dari anak-anak di Desa Pematang Kolim, Kecamatan Pelawan, Kabupaten Sarolangun, Jambi berjumlah 14 orang, Tokoh Masyarakat termasuk didalamnya adalah tokoh adat dengan total 3 orang (Kela Desa, Tokoh Adat, dan Tokoh Agama), selanjutnya adalah anak yang belum berusia 18 tahun di desa tersebut sebanyak 15 orang (anak). Hal tersebut sesuai dengan UU. No. 23 Tahun 2002 tentang perlindungan anak, Pasal 1 yang menyatakan bahwa anak merupakan seseorang yang belum berusia 18 tahun, termasuk anak yang masih dalam kandungan. Teknik pengumpulan data yang digunakan adalah wawancara mendalam, observasi, dan dokumentasi. Hal tersebut perlu untuk dilakukan oleh peneliti karena pada umumnya penelitian kualitatif melalui tiga aspek tersebut (Somantri, 2005). Teknis analisis data yang digunakan dalam penelitian ini menggunakan Teknik analisis data model interaktif (Model Miles dan Hubermen, 1984). Pada Teknik analisis data tersebut terdapat beberapa tahapan diantaranya yaitu, data collection, data display, conclusion drawing/verifyin, data reduction.

\section{HASIL DAN PEMBAHASAN}

Program transmigrasi menjadi salah satu program yang dilakukan pemerintah guna pemerataan penduduk di Indonesia. Manay (2016) menjelaskan bahwa program transmigrasi dilakukan selain untuk perpindahan penduduk juga bertujuan untuk meningkatkan perekonomian masyarakat. (Prihatin, 2013) menambahkan bahwa, adanya program tersebut tidak jarang menyebabkan kesenjangan sosial antara masyarakat lokal dan masyarakat pendatang. Hal tersebut dikarenakan, masyarakat lokal belum mampu mengikuti dan mendapatkan manfaat dari program tersebut. Salah satu daerah yang dijadikan tempat transmigrasi adalah Desa Pematang Kolim, Kecamatan Pelawan, Kabupaten Sarolangun Jambi. Guna meningkatkan persatuan di tengah keberanekaragaman budaya yang ada perlu adanya peran orang tua dalam menanamkan nilai persatuan pada anak di daerah yang tergolong wilayah tujuan transmigran tersebut. Hal tersebut perlu untuk dilakukan untuk meningkatkan integritas masyarakat di masa yang akan dating. Berdasarkan pada penelitian yang dilakukan di Desa Pematang Kolim, Kecamatan Pelawan, Kabupaten Sarolangun, Provinsi Jambi tentang peran orang tua dalam penanaman nilai persatuan pada anak di wilayah transmigrant ditemukan data yang cukup menarik untuk dikaji lebih lanjut. Dari hasil penelitian yang dilakukan dengan berbagai macam teknik pengumpulan data yang diagunkan oleh peneliti. Peran orang tua dalam menanamkan nilai persatuan pada anak mengalami peningkatan yang cukup baik akan tetapi peningkatan persatuan tersebut hanya cenderung diterapkan dalam keluarga saja. Sedangkan persatuan merupakan hal penting 
yang harus dibentuk oleh orang tua kepada anak agar kelak ketika anak terjun dalam lingkungan masyarakat memiliki kualitas sosial yang baik dan dapat menjaga persatuan di tengah keberanekaragaman yang ada.

Peran orang tua menjadi dasar utama pemebntukan karakter anak terutama didaerah transmigran yang memiliki berbagai macam latar belakang adat dan budaya yang berbeda. Terdapat beberapa peran yang perlu untuk diperhatikan dan berikut merupakan hasil penelitian yang diperoleh peneliti dari realitas peran orang tua dalam menanamkan nilai persatuan pada anak di Desa Pematang Kolim, Kecamatan Pelawan, Kabupaten Saroangun Jambi.

\section{Sebagai Pendidik}

Keluarga merupakan lembaga pertama yang dikenali anak untuk tumbuh dan berkembang. Melalui keluarga seorang anak dapat mulai mengenal dunia. Tugas orang tua dalam keluarga adalah sebagai pemberi dasar pendidikan moral, agama, dan karakter anak (Iftitah \& Anawaty, 2020). Karena, pada usia inilah anak sangat peka terhadap pengaruh dari lingkungan sekitarnya terutama keluarga (Baharun, 2016). Sebagai seorang pendidik tentu harapan orang tua adalah mendidik anak menjadi apa yang diharapkan orang tua. Sama halnya meningkatkan rasa persatuan pada anak sejak dini, agar kelak anak memiliki kualitas individu yang baik dalam bermasyarakat. Sama halnya dengan orang tua di Desa Pematang Kolim Kecamatan Pelawan, Kabupaten Sarolangun Jambi, tentu ingin mendidik anak menjadi buah hati yang sesuai dengan apa yang mereka harapkan.

Akan tetapi dalam hal menanamkan nilai persatuan pada anak, melihat kondisi masyarakat yang beragam dimana mayoritas masyarakat Desa Pematang Kolim adalah masyarakat transmigrant, peran orang tua dalam mendidik anak untuk meningkatkan nilai persatuan hanya focus pada persatuan dalam ruang lingkup keluarga itu sendiri. Orang tua lebih focus memberikan nasihat kepada anak jika anak tidak melek akan pekerjaan rumah, tidak turut serta membantu orang tua menyelesaikan pekerjaannya. Persoalan persatuan antar masyarakat lokal dan masyarakat transmigran peran orang tua untuk menanamkan nilai persatuan dalam kehidupan bersosial masih di rasa kurang. Salah satu hal yang masih sering terlihat adalah ketika anak berselisih paham dengan temannya, ada kalanya orang tua terprovokasi turut serta dalam permasalahan tersebut yang justru menimbulkan perselihan baru. Beberapa informan manyampaikan bahwa, pernah terjadi selisih paham hingga melibatkan orang tua dikarenakan permasalahan yang sebenarnya tidak perlu diselesaikan dengan cara bersitegang (E, 24 Februari 2019). Selain itu, berdasarkan hasil observasi yang didapat cara bermain anak-anak masih tergolong mengelompok dengan teman-teman yang berasal dari latar belakang yang sama, dan kurang berbaur dengan anak-anak lokal. Selain itu, beberapa anak juga mengatakan sering saling ejek antar suku yang tidak jarang berdampak pada peselisihan antar anak.

Permasalahan tersebut seharusnya menjadi perhatian yang perlu untuk lebih dipahami oleh orang tua. Permasalahan integrasi dini yang dialami anak, akan berdampak pada cara pandang anak dalam menghadapi masalah kedepannya. Ada baiknya ketika orang tua mengetahui permasalahan anak yang berkaitan dengan pergesekan persatuan, orang tua mulai mendidik dan mengarahkan. Beberapa orang tua menyampaikan bahwa, ketika anak berselisih dengan anak-anak yang berasal dari masyarakat lokal, sikap orang tua justru disarankan untuk menjauh dan mencari teman yang lain (A, 24 Februari 2022). Menjauhi pertemuan justru menghambat jiwa sosial anak yang berdampak pada meningkatkan hubungan pertemanan.

Perlu dipahami bahwa, peran orang tua sebagai pendidik pada dasarnya harus mampu mendidik anak cerdas secara akademik maupun non akademik terutama mengimplementasikan nilai persatuan di tengah keberagaman (Wijayanto, 2020). Sehingga dalam hal ini, peran orang tua sebagai pendidik dalam penanaman nilai persatuan pada anak di daerah transmigrant masih dirasa kurang. Hal tersebut mengacu pada apa yang dijelaskan 
oleh Sudiapermana (2012) bahwa orang tua sebagai pendidik harus mengerti bagaimana cara mendidik iman, moral, fisik, intelektual, psikis, sosial seksual, yang tentu di dalamnya ditujukan untuk peningkatan persatuan dalam masyarakat. Hal ini juga jika ditinjau dari segi nilai-nilai persatuan pada sila ke Tiga Pancasila, peran orang tua sebagai pendidik masih belum sesuai, karena orang tua masih belum bisa menempatkan kepentingan bangsa dan negara di atas kepentingan pribadi dan golongan (Tap MPR No. 1/MPR/2003).

\section{Sebagai Pengasuh}

Pola asuh merupakan hal penting bagi perkembangan anak. Pola asuh yang tepat akan berdampak pada pembentukan karakter anak. Hal tersebut selaras dengan apa yang diungkapkan Wijayanto (2020) bahwa pola asuh menjadi aspek penting dalam membentuk kepribadian pokok anak seperti emosi, sosial, motivasi dan intelektual anak. Terdapat beberapa macam pola asuh menurut (Santrock, 2002), yang perlu dipahami diantaranya adalah: a) Outokratis/ototarian (Otoriter): Pola asuh ini ditandai dengan adanya aturanaturan yang kaku dari orang tua dan kebebasan anak sangat di batasi. Gaya ini biasanya mengakibatkan perilaku anak yang tidak bisa bersaing secara sosial. b) Demokratis/Otoritatif: Pola asuh ini ditandai dengan adanya sikap terbuka antara orang tua dan anak. Anak yang memiliki orang tua otoritatif sering kali ceria, bisa mengendalikan diri dan mandiri, serta berorientasi pada prestasi. Gaya ini biasanya mengakibatkan perilaku anak yang bisa bersaing secara sosial. c) Permisif: Ditandai dengan adanya kebebasan tanpa batas pada anak untuk berperilaku sesuai dengan keinginannya sendiri. Hasilnya, anak tidak pernah belajar mengendalikan perilakunya sendiri dan selalu berharap mendapatkan keinginannya. Gaya pengasuhan ini biasanya mengakibatkan inkompetensi sosial anak, terutama kurangnya pengendalian diri. c) Laissez Faire: Ditandai dengan sikap acuh tak acuh orang tua terhadap anaknya. Anak-anak ini cenderung tidak memiliki kemampuan sosial. Gaya ini biasanya mengakibatkan inkompetensi sosial anak, terutama kurangnya pengendalian diri.

Penanaman nilai persatuan pada anak pada dasarnya sangat dipengaruhi oleh pola asuh orang tua terhadap anak. Jika ditinjau dari apa yang menjadi temuan di Desa Pematang Kolim, Kecamatan Pelawan, Kabupaten Sarolangun, Jambi, pola asuh orang tua terhadap anak lebih cenderung pada pola asuh yang otoriter. Dimana orang tua memberikan tugas terlebih dahulu kepada anak sebelum bermain. Selain itu, masih banyak ditemukan orang tua yang mengawasi dengan siapa anaknya bermain dalam artian masyarakat lokal atau masyarakat yang masih dalam kategori memiliki latar belakang yang sama. Beberapa orang tua tidak membolehkan anak-anaknya bermain dengan anak-anak yang berasal dari latar belakang yang berbeda. Setelah dilakukan observasi, hal tersebut juga disebabkan oleh terpisahnya pemukiman masyarakat lokal dan transmigra. Adanya jarak antara pemukiman transmigrant dan masyarakat lokal semakin menambah renggangnya hubungan persatuan antar masyarakat. Sehingga orang tua juga tidak saling mengenal satu sama lain dengan akrab. Sehingga kepercayaan pertemanan anak kurang terealisasi dengan baik.

Jika ditinjau dari segi peran orang tua sebagai pengasuh terutama dalam hal menanamkan nilai persatuan pada anak, hal tersebut dirasa belum tepat. Dikarenakan orang tua dari masing-masing kelompok tidak ada upaya saling berbaur terutama dalam kegiatan kemasyarakatan yang masing-masing memiliki kegiatan sendiri, serta masih jarang ditemukan kegiatan bersama antara masyarakat lokal dan transmigran sebagai upaya meningkatkan persatuan antar kelompok masyarakat. (Hidayah et al., 2013) menjelaskan bahwa pola asuh yang demokratis dapat mendorong perilaku anak menjadi percaya diri, sopan santun, bersahabat, mau bekerja sama, dan tentunya menjunjung tinggi nilai persatuan. Selain itu, jika ditinjau dari poin-poin nilai persatuan, hal tersebut tidak sesuai dengan nilai persatuan yang menjelaskan bahwa perlunya memajukan pergaulan demi persatuan dan kesatuan bangsa yang ber-Bhineka Tunggal Ika (C.S.T. Kansil, 1986). 


\section{Peran Orang Tua Sebagai Motivator}

Keberhasilan anak baik dalam proses belajar, terutama memahami tentang pentingnya kebersamaan dalam keberanekaragaman tidak terlepas dari adanya motivasi dari orang tua sehingga dapat menggerakkan anak untuk melakukan hal yang diharapkan. Motivasi tersebut pada dasarnya terdiri dari dua hal diantaranya yaitu motivasi yang berasal dari diri anak (intrinsic) dan motivasi yang berasal dari luar (ekstrinsik) (Choerul Anwar Badruttamam, 2018). Dari kedua hal tersebut, jika dapat diterapkan dengan baik oleh orang dapat memberikan pengaruh baik pada anak dalam meningkatkan persatuan terutama di daerah transmigran.

Peran orang tua sebagai motivator yaitu orang tua memiliki andil dalam mendukung keberhasilan anak terutama keberhasilan mewujudkan perdamaian di tengah keberanekaragaman. Banyak cara yang dapat dilakukan oleh orang tua untuk meningkatkan rasa termotivasi anak dalam meningkatkan persatuan dalam kehidupan bermasyarakat kelak. Salah satu cara yang dilakukan orang tua di Desa Pematang Kolim, Kecamatan Pelawan, Kabupaten Sarolangun, Jambi dalam memberikan motivasi untuk meningkatkan persatuan adalah dengan menceritakan sejarah keluarga kepada anak, hal tersebut diberikan kepada anak agar anak termotivasi untuk menjalin hubungan yang lebih erat dengan seluruh sanak saudaranya (I, 24 Februari 2019). Selain itu, orang tua memberikan contoh kepada anak tentang prestasi orang tua sehingga anak bangga terhadap keluarga dan orang tuanya. Dari data tersebut, peneliti coba mencari tahu bagaimana implementasi persatuan dalam keluarga dan masyarakat, dalam hal keluarga masyarakat transmigrant sangat baik meningkatkan persatuan internalnya. Hal tersebut dikarenakan mereka memiliki sejarah panjang ketika mengikuti program transmigrasi sehingga orang tua sering bercerita tentang sanak saudara yang berada di daerah asal mereka.

Akan tetapi, memberikan motivasi untuk bekerjasama dengan anak-anak yang berasal dari later belakang berbeda masih cukup sulit. Permasalahan masa lalu tidak jarang menjadi permasalahan orang tua dalam memberikan motivasi kepada anak untuk meningkatkan persatuan dalam perbedaan yang ada. Hal tersebut coba untuk dicarikan solusi oleh pemerintah daerah melalui pendidikan formal. Dengan harapan pendidikan formal dapat menyatukan persatuan sejak dini.

Pada dasarnya, cara orang tua memberikan motivasi pada anak dalam meningkatkan persatuan sudah sangat baik jika ditinjau dari ruang lingkup keluarga. Melihat kondisi Indonesia yang beranekaragam, dan kondisi Desa Pematang Kolim yang sangat multikultur seharusnya orang tua juga memotivasi anak untuk dapat bekerjasama dengan masyarakat lokal dan menjelaskan tentang masyarakat yang berbeda budaya itu seperti apa. Hal tersebut selaras dengan apa yang diungkapkan Wijayanto (2020) bahwa orang tua dapat memberikan pujian dan memberikan reward kepada anak jika semasa sekolah dapat akur dengan semua teman-teman yang berbeda latar belakang.

\section{Sebagai Model}

Peran orang tua sebagai model yang dimaksud dalam hal ini adalah orang tua sebagai teladan bagi anak. Karena, setiap pola asuh yang diberikan oleh orang kepada anak akan berpengaruh terhadap perilaku anak, yang timbul karena orang tua merupakan model bagi anak itu sendiri (Farihah et al., 2019). Peran sebagai model akan memberikan gambaran secara langsung pada anak mengenai sikap dan perbuatan yang baik atau bahkan sebaliknya tentang bagaimana mengimplementasikan nilai persatuan di daerah transmigrasi tersebut. Anak memiliki kecenderungan meniru bagaimana kebiasaan ayah dan ibunya, karena orang tua merupakan lingkungan pertama bagi anak dan memiliki ikatan yang erat terhadap anak tersebut. Kaitannya dengan peran orang tua sebagai model dalam penanaman nilai persatuan pada anak di Desa Pematang Kolim, Kecamatan Pelawan, Kabupaten Sarolangun, Provinsi Jambi adalah orang tua di desa tersebut memberikan teladan yang cukup baik dalam menanamkan nilai persatuan. Orang tua biasa mengajak anak dalam kegiatan gotong royong warga. Salah satu orang tua menyampaikan bahwa, jika dalam kegiatan kerja bakti anak-anak 
kadang diajak untuk berpartisipasi walaupun hanya melihat dan turut bermain dilokasi kerja bakti tersebut. Akan tetapi kegiatan gotong royong tersebut hanya dilakukan oleh masyarakat-masyarakat yang memiliki latar belakang yang sama seperti masyarakat transmigrant dan masyarakat lokal. Setelah dilakukan observasi lebih lanjut, dalam kegiatan masyarakat memang jarang atau bahkan sangat langka diadakan kegiatan kemasyarakatan yang melibatkan masyarakat lokal dan transmigrant.

Memahami hal tersebut, pada dasarnya kegiatan gotong royong dapat mendidik anak secara perlahan untuk bersosial dan bekerjasama dengan banyak orang, walaupun dalam kegiatan gotong royong tersebut masih didominasi dengan kelompok-kelompok masyarakat tertentu. Melihat hal tersebut pada dasarnya peran orang tua sebagai model cukup berjalan dengan baik, hal tersebut selaras dengan teori bandura (Ainiyah, 2017) yang menjelaskan bahwa, proses mengamati dan meniru perilaku dan sikap orang lain merupakan proses belajar terutama bagi anak. Dalam hal ini, ketika anak turut serta dalam kegiatan gotong royong dapat mendidik anak untuk lebih mementingkan kepentingan umum dari pada kepentingan pribadinya. Sehingga secara perlahan, implementasi nilai persatuan dapat berjalan dengan baik.

\section{SIMPULAN}

Peran orang tua dalam penanaman nilai persatuan pada anak di daerah transmigran, Desa Pematang Kolim, Kecamatan Pelawan, Kabupaten Sarolangun, Provinsi Jambi masih cukup rendah, sebagai pendidik orang tua masih terlalu fokus dalam meningkatkan persatuan dalam keluarga. Sebagai pengasuh, orang tua masih menggunakan pola asuh otoriter yang justru mempersempit jiwa sosial anak dalam berinteraksi dengan teman-temannya. Selain itu, peran orang tua sebagai motivator dalam meningkatkan persauan pada anak sejak dini masih sangat rendah terutama untuk meninkatkan persatuan antar teman. Selanjutnya sebagai seorang model, cukup berjalan baik, hanya saja masih kurangnya program pemerintah untuk meningkatkan kegiatan masyarakat yang membaur antara masyarakat transmigran dan lokal. Dari hasil penelitian ini dapat disimpulkan bahwa, proses peningkatan persatuan bukanlah hal mudah. Selain kesadaran orang tua yang harus aktif dan mampu berbaur dengan masyarakat serta memberikan pemahaman kepada anak tentang pentingnya persatuan. Pemerintah memiliki andil penting, dalam membuat program yang dapat menyatukan masyarakat dari berbagai latar belakang tersebut.

\section{UCAPAN TERIMA KASIH}

Terimakasih kepada orang tua yang selalu memberikan semangat dan motivasi kepada saya dalam melakukan segala hal positif dan bermanfaat. Selain itu termakasih kepada para pihak yang telah berkenan mensukseskan penelitian ini.

\section{DAFTAR PUSTAKA}

Achmad, A. A., Nurwati, R. N., \& Mulyana, N. (2019). Intervensi Sosial Terhadap Pengembangan Masyarakat Lokal Di Daerah Transmigrasi Desa Topoyo. Jurnal Public Policy, 5(2), 111. https://doi.org/10.35308/jpp.v5i2.1128

Ainiyah, Q. (2017). Social Learning Theory dan Perilaku Agresif Anak dalam Keluarga. Jurnal Ilmu Syari'ah Dan Hukum, 2(1), 94-98.

Alimuddin. Hos, J. A., \& M. (2019). Studi Dinamika Interaksi Sosial Antar Kelompok Etnik di Daerah Transmigrasi Kecamatan Wonggeduku Kabupaten Konawe. Jurnal Neo Societal, 4(3).

Baharun, H. (2016). Pendidikan Anak dalam Keluarga: Telaah Epistemologis. Jurnal Pedidikan, 3(2), 96-107.

C.S.T. Kansil. (1986). Hukum Tata Negara Republik Indonesia. Bina Aksara. 
Choerul Anwar Badruttamam. (2018). Peran Orang Tua dalam Meningkatkan Motivasi Belajar $\begin{array}{lllll}\text { terhadap Peserta Didik. Jurnal Cendekia, 10(02), 123-132. } & \text {. }\end{array}$ https://doi.org/10.37850/cendekia.v10i02.66

Dirjen PKPPT. (2015). Transmigrasi Masa Doeloe, Kini dan Harapan Kedepan. In Sejarah Singkat Transmigrasi. Direktorat Jenderal Penyiapan Kawasan Pembangunan Pemukiman

Transmigrasi.

https://ditjenpkp2trans.kemendesa.go.id/resources/files/a2e27404a080382134857e7e f4874c6f.pdf

Farihah, Gandamana, A., Erni, \& Sitorus, M. A. (2019). Pola Asuh Keluarga dalam Upaya Pembentukan Kemandirian Anak Berdasarkan Persepsi Budaya di Kota Medan. EJS (Elementary School Journal), 9(4), 318-326.

Hidayah, R., Yunita, E., \& Utami, Y. W. (2013). Hubungan Pola Asuh Orangtua dengan Kecerdasan Emosional Anak Usia Prasekolah (4-6 Tahun) di TK Senaputra Kota Malang. In Jurnal Keperawatan ISSN (Vol. 4, Issue 2, pp. 131-135).

Iftitah, S. L., \& Anawaty, M. F. (2020). Peran Orang Tua Dalam Mendampingi Anak Di Rumah Selama Pandemi Covid-19. JCE (Journal of Childhood Education), 4(2), 71. https://doi.org/10.30736/jce.v4i2.256

Kusumastuti, A., \& Ahmad Mustamil Khoiron. (2019). 'Metode Penelitian Kualitatif. In Japanese circulation journal (Vol. 57). PT Remaja Rosdakarya.

Lindayanti, L., \& Zaiyardam, Z. (2016). Konflik dan Integrasi Dalam Masyarakat Plural: Jambi 1970-2012. Paramita: Historical Studies Journal, 25(2), 169. https:// doi.org/10.15294/paramita.v25i2.5129

Manay, H. (2016). Proyek Demografi Dalam Bayang-Bayang Disintegrasi Nasional: Studi Tentang Transmigrasi Di Gorontalo, 1950-1960. Jurnal Sejarah Citra Lekha, 1(2), 93. https://doi.org/10.14710/jscl.v1i2.12766

Maulana, I., Program, M., Pendidikan, S., Besar, A., Program, D., Pendidikan, S., Abulyatama, U., \& Besar, A. (2019). Universitas Abulyatama Konflik Sosial Masyarakat Transmigrasi Dengan Masyarakat Lokal Dalam Kehidupan Bermasyarakat. Kandidat, 1(2), 113-125.

Miyanti, Y., Rini, C., S., H. L., \& A. (2017). Konflik Dalam Relasi Sosial Masyarakat Jawa Dan Lampung Di Wilayah Transmigrasi (Studi Kasus di Desa Bandar Agung Kecamatan Bandar Sribhawono Kabupaten Lampung Timur). Solidarity: Journal of Education, Society and Culture, 6(2), 189-201.

Monstasir, L. O., Jamiludin, \& Syahrun. (2017). Kesenjangan Sosial Ekonomi dan Politik Pada Masyarakat Transmigrasi di Kecamatan Tiworo Tengah Kabupaten Muna Barat. Wahana Kajian Pendidikan IPS, 1(2), 85-89.

Nur Utami, A. C., \& Raharjo, S. T. (2019). Pola Asuh Orang Tua Dan Kenakalan Remaja. Focus : Jurnal Pekerjaan Sosial, 2(1), 150. https://doi.org/10.24198/focus.v2i1.23131

Prihatin, R. B. (2013). Revitalisasi Program Transmigrasi. Aspirasi: Jurnal Masalah-masalah Sosial, 4(1), 57-64.

Punia, I. N., \& Budi Nugroho, W. (2020). Bali Diaspora di Daerah Transmigrasi: Representasi Kearifan Lokal Bali di Kabupaten Bolaang Mongondow, Sulawesi Utara. Jurnal Kajian Bali (Journal of Bali Studies), 10(1), 49. https://doi.org/10.24843/JKB.2020.v10.i01.p03 Santrock, J. . (2002). Lige Span Development: Perkembangan Masa Hidup. Erlangga.

Sarmita, I. M. (2014). Potensi Konflik di Daerah TUjuan Transmigrasi (Kasus Sampit dan Mesuji). Media Komunikasi Geografi, 15(1), 45-59. 
Somantri, G. R. (2005). Memahami Metode Kualitatif. In Makara Human Behavior Studies in Asia (Vol. 9, Issue 2). Alfabeta. https://doi.org/10.7454/mssh.v9i2.122

Sudiapermana, E. (2012). Pendidikan Keluarga Sumberdaya Pendidikan Sepanjang Hayat. In Bandung: Edukasia pers. Edukasia.

Suharno. (2015). Kebijakan Berbasis Politik Rekognisi dan Resolusi Konflik Etnik. SOCIA: Jurnal Ilmu-Ilmu Sosial, 12(1). https:// doi.org/10.21831/ socia.v12i1.5320

Sumolang Steven dan Peggy Janeke. (2018). Penataan Konflik Sosial Pada Masyarakat Dumoga Di Kabupaten Bolaang Mongondow. Kementerian Pendidikan dan Kebudayaan Sulawesi Utara.

Suryawan, N. W., \& Danial, E. (2016). Implementasi Semangat Persatuan Pada Masyarakat Multikultural Melalui Agenda Forum Kerukunan Umat Beragama (Fkub) Kabupaten Malang. Humanika, 23(1), 46. https:// doi.org/10.14710/humanika.23.1.46-60

Tolliver-Lynn, M. N., Marris, A. M., Sullivan, M. A., \& Armans, M. (2021). The Role of The Parent-child Relationship in Fostering Resilience in American Indian/Alaskan Native children. Journal of Community Psychology, 49(2), 419-431. https://doi.org/10.1002/jcop.22468

Wijayanto, A. (2020). Peran Orangtua dalam Mengembangkan Kecerdasan Emosional Anak Usia Dini. Diklus: Jurnal Pendidikan Luar Sekolah, 4(1), 55-65. https:// doi.org/10.21831/diklus.v4i1.30263

Yulmardi. (2019). Transmigrasi di Provinsi Jambi (Kesejahteraan dan Sebaran Permukiman Generasi Kedua Transmigran. CV. Peran Persada. 